U. S. DEPARTMENT OF COMMERCE BUREAU OF STANDARDS

\title{
AMERICAN NATIONAL STANDARD
} SCREW THREADS

(COARSE AND FINE THREAD SERIES)

\section{COMMERCIAL STANDARD CS24-30}

\section{ELIMINATION OF WASTE}

Through

SIMPLIFIED COMMERCIAL PRACTICE 
Below are described some of the series of publications of the Department of Commerce which deal with various phases of waste elimination.

\section{SIMPLIFIED PRACTICE RECOMMENDATIONS}

These present in detail the development of programs to eliminate unnecessary variety in sizes, dimensions, styles, and types of over 100 commodities. They also contain lists of associations and individuals who have indicated their intention to adhere to the recommendations. These simplified schedules, as formulated and approved by the industries, are indorsed by the Department of Commerce.

\section{COMMERCIAL STANDARDS}

These are developed by various industries under a procedure similar to that of simplified practice recommendations. They are, however, primarily concerned with considerations of grade, quality, and such other characteristics as are outside the scope of dimensional simplification.

\section{AMERICAN MARINE STANDARDS}

These are promulgated by the American Marine Standards Committee, which is controlled by the marine industry and administered as a unit of the division of simplified practice. Their object is to promote economy in construction, equipment, maintenance, and operation of ships. In general, they provide for simplification and improvement of design, interchangeability of parts, and minimum requisites of quality for efficient and safe operation.

Lists of the publications in each of the above series can be obtained by applying to the Bureau of Standards, Washington, D, C. 


\section{AMERICAN NATIONAL STAI SCREW THREADS} (COARSE AND FINE THREAD SERIES)

\section{COMMERCIAL STANDARD CS24-30}

[Issued September 16, 1930]

Effective Date, July 1, 1930

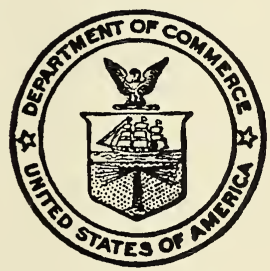

UNITED STATES

GOVERNMENT PRINTING OFFICE

WASHINGTON : 1930 


\section{NOTE}

This commercial standard makes available for convenient use, six of the most essential tables of dimensions of fastening screws as published in the 1928 Report of the National Screw Thread Commission (Sec. III and Appendix 4), Bureau of Standards Miscellaneous Publication No. $89,{ }^{1}$ and is identical therewith. Figure and table numbers are identical with those in the Report of the N. S. T. C. for convenience in making references.

1 The complete report may be procured from the Superintendent of Documents, U. S. Government Printing Office, Washington, D. C., at 50 cents per copy. 


\section{COMMERCIAL STANDARD CS24-30}

\section{ACCEPTORS}

\section{ASSOCIATIONS}

Bolt, Nut, and Rivet Manufacturers Association, Port Chester, N. Y.

Southern Hardware Jobbers Association, New Orleans, La.

Southern Supply \& Machinery Dealers Association, Richmond, Va.

\section{FIRMS}

Acme Machine Tool Co., The, Cincinnati, Ohio. Adams Co., The, Dubuque, Iowa.

Allied Products Corporation, Victor-peninsular division,

Detroit, Mich.

Almond Manufacturing Co., T. R., Ashburnham, Mass.

Alvord-Polk Tool Co., Millersburg, Pa.

American Manganese Bronze Co., Philadelphia, Pa.

American Ring Co., Waterbury, Conn.

American Screw Co., Providence, R. I.

Armstrong Manufacturing Co., The, Bridgeport, Conn.

Arrow Head Steel Products Co., Minneapolis, Minn.,

(in principle).

Atlas Bolt \& Screw Co., The, Cleveland, Ohio.

Autocar Co., Ardmore, Pa.

Autoscrew Co., New York, N. Y.

Babson Dow Manufacturing Co., Roxbury, Mass.

Bard Manufacturing Co., Royersford, $\mathrm{Pa}$.

Barnes Drill Co., Rockford, Ill.

Bath \& Co. (Inc.), John, Worcester, Mass.

Bousch \& Lomb Optical Co., Rochester, N. Y.

Baush Machine Tool Co., Springfield, Mass, (in principle).

Bell Co. (Inc.), The David, Buffalo, N. Y.

Bethlehem Steel Co., Lebanon, Pa.

Biglow \& Co. (Inc.), L. C., New York, N. Y.

Bommer Spring Hinge Co., Brooklyn, N. Y.

Bristol Co., The, Waterbury, Conn.

Brown \& Sharpe Manufacturing Co., Providence, R. I.

Buffalo Bolt Co., North Tonawanda, N. Y.

Chase Companies (Inc.), Waterbury Manufacturing Co., division, Waterbury, Conn.

Chicago Screw Co., Chicago, Ill.

Clark Bros. Bolt Co., Milldale, Conn.

Clendenin Bros. (Inc.), Baltimore, Md.

Cleveland Cap Screw Co., The, Cleveland, Ohio.

Cleveland Twist Drill Co., Cleveland, Ohio.

Cleveland Wrought Products Co., The, Cleveland, Ohio.

Columbus Bolt Works Co., The, Columbus, Ohio.

Commercial Tool Co., The, Cleveland, Ohio.

Comtor Co., The, Waltham, Mass.

Conant \& Donelson Co., Conway, Mass.

Continental Wood Screw Co., New Bedford, Mass.

Corbin Screw Corporation, The, New Britian, Conn.

Cox \& Sons Co., The, Bridgeton, N. J., (in principle).

Curtis Screw Co, (Inc.), Buffalo, N. Y.
Dallett Co., The, Philadelphia, $\mathrm{Pa}$.

Davenport Machine Tool Co. (Inc.), Rochester, N. Y.

Davis \& Hemphill, Elkridge, Md.

Detroit Screw Works, Detroit, Mich.

Eastern Machine Screw Corporation, New Haven, Conn.

Eastwood Wire Corporation, Belleville, N. J.

Economy Engineering Co., The, Willoughby, Ohio.

Ekstrom Carlson \& Co., Rockford, Ill.

Electric Boat Co., Groton, Conn.

Erie Forge \& Steel Co., Erie, Pa.

Essley Machinery Co., The E. L., Chicago, Ill.

Eureka Tool \& Machine Co., Newark, N. J.

Federal Huber Co., Plano, Kendall County, Ill.

Flannery Bolt Co., Bridgeville, Pa.

Foster Machine Co., Elkhart, Ind.

Gaskell \& Son, (Inc.), William, Brooklyn, N. Y.

General Manufacturing Co., The, Waterbury, Conn.

General Motors Corporation, Detroit, Mich.

Geometric Tool Co., The, New Haven, Conn.

Gibbs \& Cox (Inc.), New York, N. Y.

Gisholt Machine Co., Madison, Wis.

Globe Products Co., The, Cleveland, Ohio.

Grabler Manufacturing Co., The, Cleveland, Ohio.

Greenfield Tap \& Die Corporation, Greenfield, Mass.

Gurley, W. \& L. E., Troy, N. Y.

Hardinge Bros., Chicago, Ill.

Hardware Products Co., Boston, Mass.

Harper Co., H. M., Chicago, Ill.

Hartford Machine Screw Co., Hartford, Conn.

Haynes Stellite Co., Kokomo, Ind.

Indicating Calipers Corporation, New York, N. Y.

Jenckes Knitting Machine Co., Pawtucket, R. I.

John-sons Gage Works, Hartford, Conn.

Jolinson Rule Manufacturing Co., E. P., Chicago, Ill.

Kalman Steel Co., Chicago, Ill.

Kinner Airplane \& Motor Corporation, Glendale, Calif.

Lamson \& Sessions Co., The, Cleveland, Ohio.

Landis Machine Co., Waynesboro, Pa.

Lang Tool Co., The C. W., Dayton, Ohio.

Lanman Co., The E. B., East Chicago, Ind.

Lehmann Machine Co., St. Louis, Mo.

Livingston Manufacturing Co., Rockland, Me.

MacLean-Fogg Lock Nut Co., Chicago, Ill.

Macy \& Co. (Inc.), R. H., New York, N. Y.

Manufacturers' \& Inventors' Electric Co., New York,

N. Y.

Maryland Bolt \& Nut Co., The, Mount Washington,

Baltimore, Md.

Meisel Press Manufacturing Co., Boston, Mass.

Merrill Bros., Maspeth L. I., N. Y.

Michigan Screw Co., Lansing, Mich.

Milled Screw Products Co., Chicago, Ill.

Mitchell Engineering Co., The, Springfield, Ohio. 


\section{STANDING COMMITTEE}

A few changes, for the purpose of filling vacancies, have been made in the original standing committee appointed to consider annually any comment or suggestions for the improvement of the commercial standard. The personnel of this committee is now as follows:

Dr. BriAdroRd NGYES, Jr., chairman, Taylor Instrument Cos., Rochester, N. Y. W. L. Crounse, National Wholesale Druggists' Association, Washington, D. C FrIEND LEE MICKLE, State department of health, Hartford, Conn.

E. F. MUELler, Bureau of Standards, Washington, D. C.

Oтто W. ScHLEgermuch, Schlegelmilch Bros., Long Island City, N. Y.

P. J. Peconet.I.A, Pecorella Manufacturing Co., Brooklyn, N. Y.

Maj. Robert Skexton, major, Medical Corps, United States Army, Army Base, Brooklyn, N. Y.

Jонn M. Sмrтн, Hahnemann Hospital, Philadelphia, Pa.

\section{EFFECTIVE DATE}

The effective date for new production was set for June 1, 1932.

\section{CERTIFICATION PLAN}

The certification plan as applied by the Bureau of Standards to commercial standards consists in the compilation and distribution of lists of manufacturers who are willing, when requested to do so, to certify to purchasers that products supplied by them comply with all the requirements and tests set forth in nationally recognized commercial standards. The plan is also applied to selected Federal specifications.

These lists are available on request to individual consumers, consumer groups, companies, and, in fact, to any prospective puchasers, for their guidance.

The benefits now derived from the use of specifications by large consumers are thus made immediately available to the small consumer, with incidental advantage to the larger consumers of convenience in ordering and accepting material with fewer laboratory tests. The manufacturer also benefits from the well-known economies accompanying "mass production."

The lists of manufacturers " willing to certify" to the quality of certain commodities are made by corresponding with, as nearly as possible, all the manufacturers of that product and listing only those who signify their willingness to certify to the purchaser, when requested to do so, that the commodities delivered actually comply with the commercial standard.

Obviously, the purchaser making use of the lists of "willing to certify" manufacturers will select therefrom such manufacturers as are known (or assumed) by him to be reliable.

The trend toward the purchase of materials of certified quality from sources shown on such "willing to certify" lists supplies added incentive to standardization on the part of other producers, and thus the benefits of the certification plan will be felt by purchasers either directly or indirectly, whether or not they make use of the plan themselves. 


\section{INDEXING TITLE}

The self-indexing title appearing in the upper left-hand corner of front page of cover is identical with that used in the Federal Standard Stock Catalogue. The corresponding Federal Standard Stock Catalogue and Federal specification group classification is GG.

\section{COMMERCIAL STANDARDS PROCEDURE}

Industry has long recognized the value of a wide application of specifications developed and approved by nationally recognized organizations. For those desirous of securing this result the Bureau of Standards has a procedure whereby such specifications, properly indorsed, may be printed as official publications of the Department of Commerce and promulgated as "commercial standards." The cooperation of the Bureau of Standards for this purpose is available only upon written request.

The division of trade standards is not designed to act as a standardizing body, neither does it engage in the preparation of specifications. Its function is mainly coordinatory in character, since its chief mission is to invite attention to a standard or a specification which any branch of industry may recommend for promulgation on a national basis; to determine its eligibility for promulgation; to publish and broadcast it in the event the prerequisites of procedure have been met, including a satisfactory majority acceptance; to facilitate the application of the certification plan for the assurance and convenience of the purchaser; to provide means for periodic audits of adherence; and to cooperate with the Bureau of Foreign and Domestic Commerce in determining the desire of industry relative to translation and promulgation of such specifications as a basis for foreign commerce.

Commercial standardization parallels simplified practice in many respects, although there are certain fundamental differences in their objectives. In general, it may be said that a simplification covers types, sizes, and varieties of a commodity which are retained by industry on the basis of demand, whereas a commercial standard establishes definite requirements as to grade, quality, or dimensional tolerances in addition to and distinct from any limitation of variety desired and accepted by the industry.

\section{ORGANIZATION AND DUTIES OF STANDING COMMITTEE}

In order to carry on the aims and desires of the industry in the standardization of their product, a standing committee is appointed at the general conference. This committee consists of members from each division of the industry, namely, producers, distributors, and consumers, and thus reflects the well-balanced viewpoint of all concerned.

The members of the committee receive all suggestions regarding the commercial standard and consider its revision in the event that such action is desirable and mutually beneficial.

If revision is unnecessary, the commercial standard is reaffirmed in its existing form; but if any important changes are found de- 
sirable, their adoption is recommended by the committee, whereupon the industry is again solicited for written acceptance of the standard in its revised form.

The committee is in effect a centralizing agency for criticisms and comments regarding the commercial standard and is charged with the responsibility of recommending revisions to keep the standard abreast with current industrial practice.

The proper functioning of the committee requires that, when necessary, its members be willing to attend meetings held at some central place, although in most cases it will be possible to conduct the work by correspondence.

When deceptions in reference to the commercial standard are reported to the standing committee, it applies moral suasion or such other corrective measures as seem desirable. The Department of Commerce has no "police power" to compel adherence, nor follow-up inspection to check conformity thereto, so it rests upon the industry itself and the standing committee to do all in its power to encourage all divisions of the industry to follow the provisions of the commercial standard and contribute in every way possible to its general adoption and usefulness.

\section{YOUR COOPERATION}

As a producer, distributor, or consumer of some of the commodities for which commercial standards have already been established, you are in a position to avail yourself of the benefits arising from the use of quality standards.

The first step is a declaraton in favor of the standard by recording your intention to adhere, as closely as circumstances will allow, to the standards for those products which you may buy or sell.

The receipt of your signed acceptance will permit the listing of your company in new editions of the commercial standards that you accept.

The acceptance of a commercial standard is an entirely voluntary action and applies to the production, sale, and use of stock items. It is not meant to interfere with the introduction, manufacture, or sale of special sizes and types sometimes required, nor to restrict the ingenuity of the producer in the employment of new materials, processes, or methods.

Commercial standards may be procured singly or in quantities at a nominal price from the Superintendent of Documents, Washington, D. C. Prices will be furnished upon request.

Trade associations and individual companies often distribute large numbers of the printed standard for the information and guidance of their members or customers. In such cases it is possible to extend the scope and degree of adherence by urging each recipient to send in an acceptance, bearing in mind that the practical value of any standardization is measured by the observance it receives.

An acceptance form for the commercial standard herein covered is included on page 15 . 


\section{ACCEPTANCE OF COMMERCIAL STANDARD}

Please sign and return this sheet to Division of Trade Standards, Bureau of Standards, Washington, D. C.

\section{Date}

Division of Trade Standards,

Bureau of Strandards,

Washington, $D . C$.

Gentlemen: We, the undersigned, do hereby accept the original draft of the commercial standard, as our standard practice in the production, ${ }^{1}$ distribution, ${ }^{1}$ or use $^{1}$ of clinical

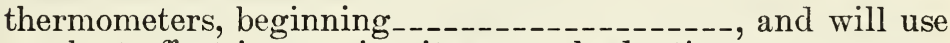
our best effort in securing its general adoption.

To permit intelligent review of the effectiveness of the commercial standard every year by an accredited committee of all interests, working in cooperation with the Department of Commerce, we plan to supply all data, upon request, which may be necessary for the development of constructive revisions. It is understood that any suggested modifications will be submitted as soon as formulated, and shall not be promulgated until accepted in form similar to this recommendation.

Signature

(Above signature should be in Ink)

(Kindly typewrite or print the following lines)

Title

Company

Street address

City and State

We are members of the following associations or other organizations interested in the production, sale, or use of clinical thermometers.

1 Please designate which group you represent by drawing lines through the the other two. In the case of related interests, trade papers, colleges, etc., desiring to record their general approval, the words "In principle" should be added after the signature. 


\section{TO THE ACCEPTOR}

In signing the acceptance blank, please bear the following points clearly in mind:

1. Adherence.-The Department of Commerce has no regulatory powers to enforce adherence to the commercial standards. Instead, this program is based on voluntary cooperation and self-government in industry. To make this specific standardization operate as a satisfactory example of self-government, it is highly desirable that it be kept distinct from any plan or method of governmental regulation or control. It will be successful according to the degree to which manufacturers, distributors, and purchasers adhere to its terms and conditions.

2. The industry's responsibility.-The department cooperates only on the request of the industry, and assumes no responsibility for industrial acceptance or adherence. This program was developed by the industry on its own initiative. Its success depends wholly on the active cooperation of those concerned.

3. The acceptor's responsibility. - You are entering into an entirely voluntary arrangement, whereby the members of the industry-the distributors and consumers of the product, and others concerned-hope to secure the benefits inherent in commercial standardization. Those responsible for this standard realize that instances may occur in which it will be necessary to supply or purchase items not included therein. The purpose is, however, to secure wider support for nationally recognized standards covering grade, quality, and other characteristics of products. Consumers can make the program a success if, in their purchasing, they will make a definite and conscientious effort to specify in terms of this commercial standard.

4. The department's responsibility.-The function performed by the Department of Commerce is fourfold: First, to act as a coordinator to insure adequate consideration of the needs of all interests; second, to supply such assistance and advice in the development of this program as past experience with similar programs may suggest; third, to solicit and record the extent of adoption and adherence to the standard; and fourth, to add all possible prestige to this standardization movement by publication and promulgation if and when it is adopted and accepted by all elements directly concerned. 




\section{COMMERCIAL STANDARDS}

CS No.

$0-30$. The commercial standards service and its value to business.

1-32. Clinical thermometers (first revision).

2-30. Mopsticks.

3-28. Stoddard solvent.

4-29. Staple porcelain (all-clay) plumbing

5-29. Steel pipe nipples.

6-31. Wrought-iron pipe nipples (first revision).

7-29. Standard weight malleable iron or steel screwed unions.

8-30. Plain and thread plug and ring gage blanks.

9-29. Builders' template hardware.

10-29. Brass pipe nipples.

11-29. Regain of mercerized cotton yarns.

12-29. Domestic and industrial fuel oils.

$13-30$. Dress patterns.

14-31. Boys' blouses, button-on waists, shirts and junior shirts.

15-29. Men's pajamas.

16-29. Wall paper.

17-32. Diamond core drill fittings (first revision) (in preparation).

18-29. Hickory golf shafts.

19-32. Foundry patterns of wood.

20-30. Staple vitreous china plumbing fixtures.

Norict.-Those interested in commercial standards with a view toward accepting them as a basis of everyday practice in their industry, may secure copies of the above standards, while the supply lasts, by addressing the Division of Trade Standards, Bureau of Standards, Washington, D. C.

CS No. Item

21-30. Interchangeable ground glass joints 22-30. Builders' hardware (nontemplate).

23-30. Feldspar.

24-30. Standard screw threads.

25-30. Special screw threads.

26-30. Aromatic red cedar closet lining.

27-30. Plate glass mirrors.

28-32. Cotton fabric tents, tarpaulins, and covers.

29-31. Staple seats for water-closet bowls.

30-31. Colors for sanitary ware.

31-31. Red cedar shingles.

$32-31$. Cotton cloth for rubber and pyroxylin coating.

33-32. Knit underwear (exclusive of rayon).

34-31. Bag, case, and strap leather.

35-31. Plywood (hardwood and eastern red cedar).

36-31. Fourdrinier wire cloth.

37-31. Steel bone plates and screws.

38-31. Hospital rubber sheeting.

39-32. Wool and part wool blankets (in preparation).

40-32. Surgeons' rubber gloves (in preparation).

41-32. Surgeons' latex gloves (in preparation). 
